\title{
ANALYSIS OF INDEPENDENT ENERGY SAVING POSSIBILITIES IN FLATS OF APARTMENT BUILDINGS
}

\author{
Vytautas Adomavicius \\ Kaunas University of Technology, Lithuania \\ vytautas.adomavicius@ktu.lt
}

\begin{abstract}
The article provides results of measurements performed in the experimental apartment building in order to explore opportunities to improve the efficiency of energy usage in this and in other similar buildings. The experiments were performed in the apartment building located on the KTU campus and renovated a few years ago. After analysing the results of the performed measurements, it was found that even after the renovation there are many opportunities to significantly improve the energy efficiency in this apartment building and most probably in other similar buildings as well. Proposals to use various measures to increase the energy efficiency of a building have been combined with the need to create a microclimate with optimal parameters recommended by global construction, government, and health organizations for living and working spaces so that residents can live, work and relax comfortably. Parameters of thermal energy circulating in the building, amounts of the heat energy used for the production of one cubic meter of domestic hot water, variations of indoor and outdoor temperatures, as well as variations of indoor and outdoor humidity over a long time, photographic and thermo graphic images of heat wasting parts (windows and doors) were obtained experimentally. The obtained parameters are analyzed, the problems causing unnecessary heat loss are found out and suggestions for reducing these losses are presented. Implementation of untapped potential energy-saving measures in apartment buildings could result in significant energy savings.
\end{abstract}

Keywords: energy-efficient buildings, microclimate parameters in apartments, renovated buildings, potential of energy-saving measures.

\section{Introduction}

The number of people, who have realized that previous generations have left for them many largescale problems, have formed a large majority in the world over the last three decades and now they want to solve those problems as soon as possible. The fate of future generations inheriting the planet Earth will depend on the success of the green revolution, which currently has the fastest growth in the energy and transport sectors. Much useful work for the green revolution can also be done in the field of energy efficiency in buildings.

Among the biggest problems are various types of environmental pollution including the burning of fossil fuels. Energy, industry, agriculture, transport, and buildings have so far been the most polluting sectors of the world economy. All technologies based on fossil fuel combustion are contributing to the greenhouse effect and the phenomenon of climate change. The waste of energy in the stages of energy production, distribution and use exacerbates these problems.

Now we can observe how the energy sector is rapidly shifting to renewable energy sources, and vehicles of all types are being electrified. However, this is not enough to tackle climate change rapidly and effectively. Very much have to be done for the decarbonisation of other sectors of the global economy including buildings, both in urban and rural areas. The energy efficiency of buildings can be significantly improved as well and there are many ways to do this. In apartment buildings, some energysaving measures have to be implemented with the consent of all apartment owners, for example, the thermal insulation of buildings, modernization, and management of the DHW system. The apartments also have the potential to save energy independently. This article analyses how apartment owners can make a significant contribution to reducing energy waste throughout an apartment building by saving energy in their own apartments.

\section{Materials and methods}

Consumption of thermal energy circulating in the experimental apartment building for space heating and production of the domestic hot water (DHW) were measured by the certified heat energy meters installed during the renovation of the building. Volumes of DHW consumed in apartments were measured by the domestic hot water meters. Thermovisor was used for making thermo graphic images of the most problematic heat energy-wasting parts of buildings, such as windows and doors. Thermal energy consumption for heating the entire building and individual apartments is measured periodically 
at all times. Additional heat energy meters are installed for measurements of heat loss in the pipeline from the building's heating unit to the inlets to the apartments. Such losses are measured in both the apartment heating system and the DHW production system. Such measurements and calculation of thermal energy losses allow seeing a real picture in thermal energy systems and the possibility to make detectable conclusions. The period chosen for the research of heat energy losses was 3 years - 20162018. The readings of all heat meters were recorded every month. An automatic meteorological station was used to measure the temperature and humidity indoors and outdoors over a long period of time (15.10.2017-01.11.2018). The received results of measurements later were visualized and analysed. Review of information on the topics of microclimate in buildings and energy- saving, summarizing of reviewed information and experimental data, formulation of conclusions and recommendations were the final activities of this study. All 75 apartments were covered by the study.

\section{Results and discussion}

The main technical parameters of the investigated apartment building related to the use of thermal energy for space heating and DHW are presented in Table 1. The building was renovated in 2012. Its outdoor walls were covered with thermal insulation and the thermal unit was upgraded by connecting the radiators in parallel to the district heating water pipes. The radiators were equipped with thermostats so that the residents could regulate the temperature in the rooms themselves.

Technical parameters of the researched apartment building

\begin{tabular}{|l|c|c|}
\hline \multicolumn{1}{|c|}{ Main parameters of the researched apartment building } & Values & Notes \\
\hline Total heated area, $\mathrm{m}^{2}$ & 6750 & Number of apartments -75 \\
\hline Average annual consumption of $\mathrm{DHW}, \mathrm{m}^{3}$ & 3600 & Number of dwellers -270 \\
\hline Average daily consumption of DHW, $\mathrm{m}^{3}$ & 10 & - \\
\hline Rated temperature of the DHW in the apartment building, ${ }^{\circ} \mathrm{C}$ & $55 \pm 2$ & Programmable controller \\
\hline Average amount of energy for production $1 \mathrm{~m}^{3} \mathrm{DHW}, \mathrm{kWh} \cdot \mathrm{m}^{-3}$ & 45.95 & - \\
\hline Annual consumption of heat energy for $\mathrm{DHW}$ in $2017, \mathrm{MWh}$ & 508.75 & - \\
\hline Annual consumption of heat energy for $1 \mathrm{~m}^{2}$ heating, $\mathrm{kWh} \cdot \mathrm{m}^{-2}$ & 48.9 & Depends on the year \\
\hline
\end{tabular}

Renovation of the building gave good results - the expenses of the apartment heating decreased by about 2-3 times. Average energy consumption for heating of all heated areas in the building and measured heat losses in the energy supply lines between the thermal unit and apartments during all months of the heating season in the years 2016-2018 are shown in Fig. 1.

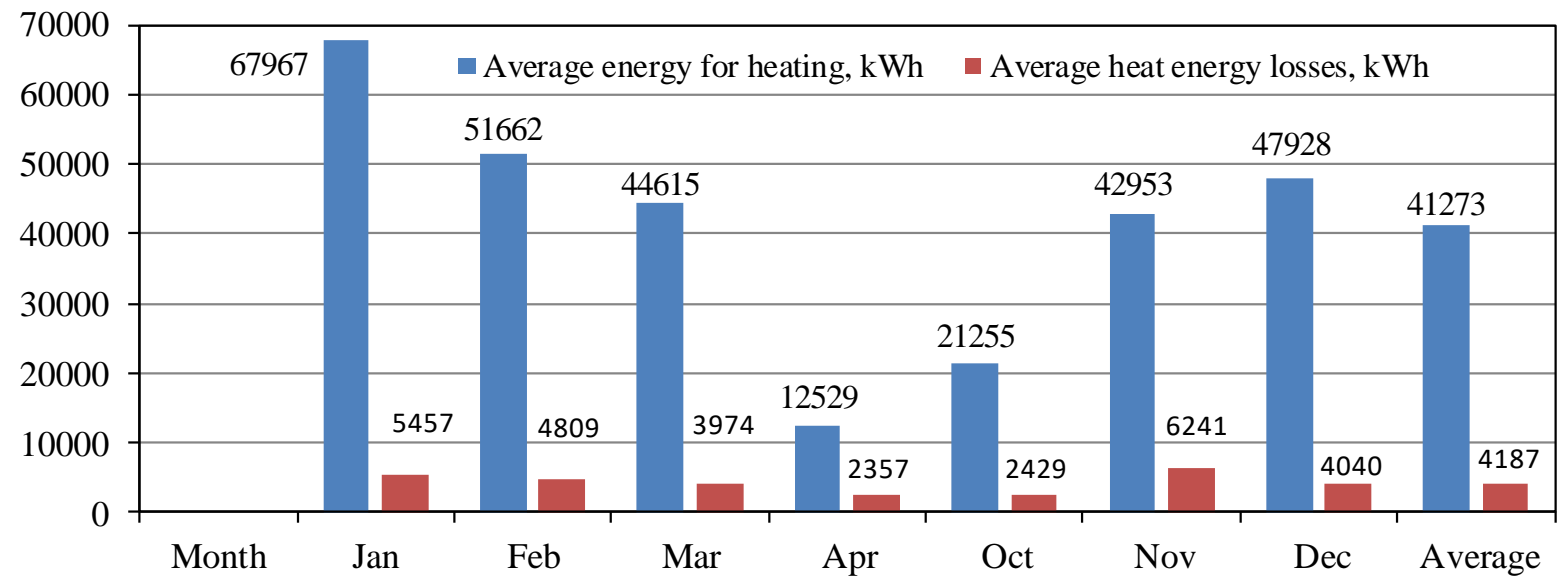

Fig. 1. Average heat energy used for the building heating and average heat losses (2016-2018)

Average energy used per season for $1 \mathrm{~m}^{2}$ area heating made up $48.9 \mathrm{kWh}$ and average energy losses - $10.14 \%$. A majority of apartment owners say, they are keeping the air temperature in rooms about $+23{ }^{\circ} \mathrm{C}$ and some of them even more. Thus, there is a certain potential for heat energy savings in the apartments because the scientific, health, and governmental organisations recommend a bit different parameters of the air temperature for keeping optimal microclimate in living rooms or offices. 
Air temperature and relative humidity in buildings are some of the most important parameters for maintaining a healthy microclimate. A lot of information is available on this topic [1-9]. The most commonly recommended air temperature range is between 18 and $23{ }^{\circ} \mathrm{C}$ and the relative humidity is between 40 and 60 (70)\% RH. The air temperature variations in the experimental room and outdoors during the period from 15.10.2016 to 01.11.2017 are presented in Fig. 2 and the relative humidity during the same period - in Fig.3.

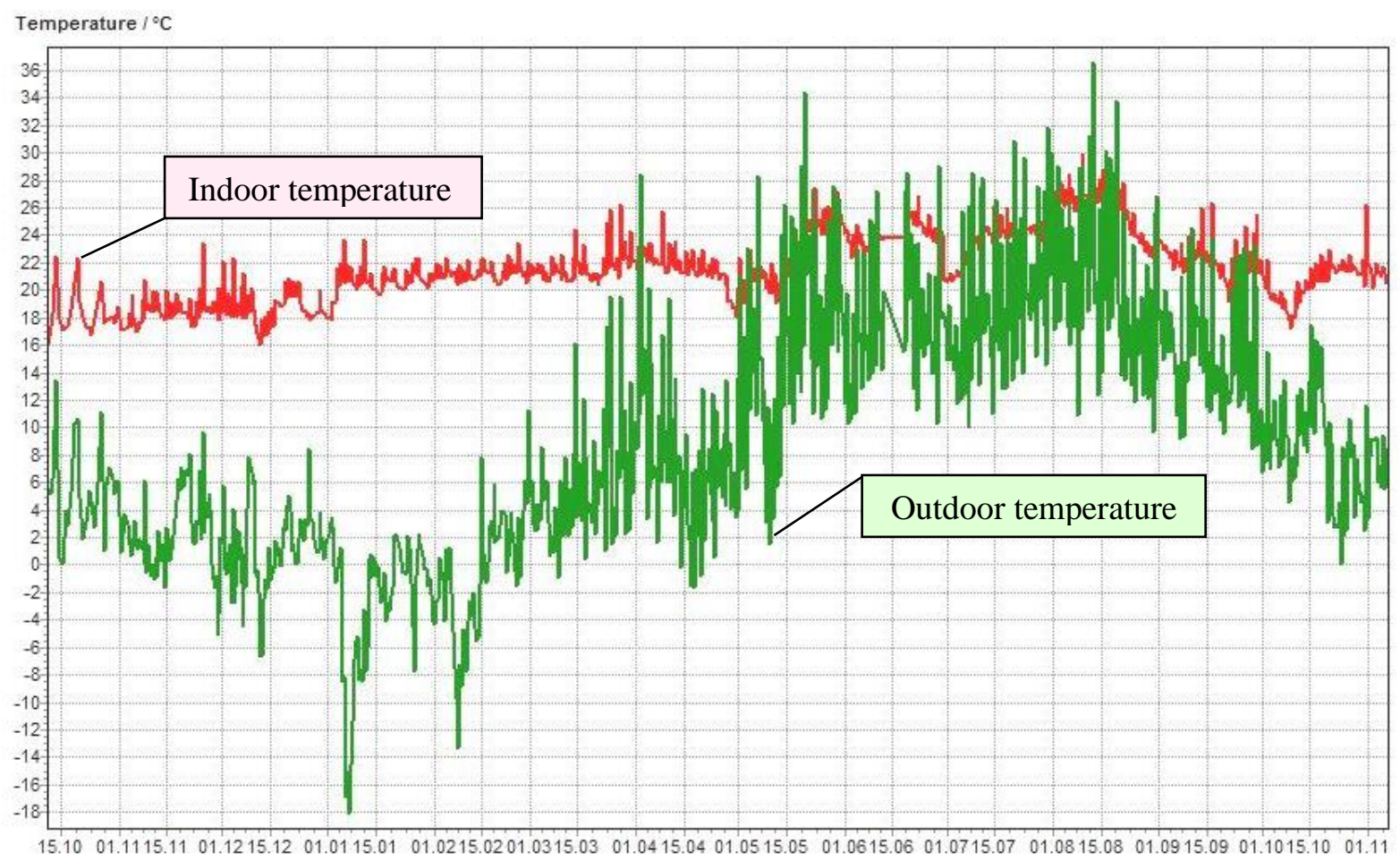

Fig. 2. Variations of the indoor temperature in the experimental room and outdoors

Buildings that do not have an optimal microclimate often have the so-called sick building syndrome (SBS), because people in them often get sick or feel unwell. If the temperature is low, inhabitants often catch cold and get sick, if they do not wear warm clothes. If the temperature is too high, it is frustrating with heat, reducing productivity, especially in case of mental work. Studies have shown that the optimum temperature for mental activities is $21-22^{\circ} \mathrm{C}$ [5]. Too high temperature is more frustrating than too low. The minimum temperature with warm clothing can be lower, about $18-19^{\circ} \mathrm{C}$. The bedroom night temperature can be even slightly lower, about $16-17^{\circ} \mathrm{C}$. The Lithuanian Minister of Health approved the limit values of air temperature in residential and public premises during the heating season from 18 to $22^{\circ} \mathrm{C}$ (Order $\mathrm{HN}$ 42: 2009). Fig. 2 shows the approximate compliance of the air temperature in the experimental room with the limit values during the heating season, but the temperature fluctuations are quite significant.

Variations of the air relative humidity in the experimental room and outdoors during the period from 15.10.2016 to 01.11.2017 are presented in Fig. 3. Humidity in the premises of buildings affects not only the health of people, but also the building itself. Microorganisms, bacteria, and viruses are not affected uniformly by humidity. Bacteria multiply better when the humidity is higher. The potential for virus transmission increases when the humidity is below $35 \%$ and above $65 \%$. When the humidity exceeds $70 \%$, favorable conditions are created for mites. Air humidity from about $80 \%$ and higher is favorable for moulds that are harmful to buildings. Low humidity from 40 to $10 \% \mathrm{RH}$ is harmful to the health of people with diseases such as allergies and asthma [9].

Lower humidity in buildings is associated with higher air temperatures - the higher the air temperature in heated rooms, the lower the humidity. It follows that the health of the occupants of apartment buildings and institutions would be more beneficial, if they lived and worked in cooler rather than in significantly overheated premises. Lack of heat can be compensated by warmer clothing, if needed. 


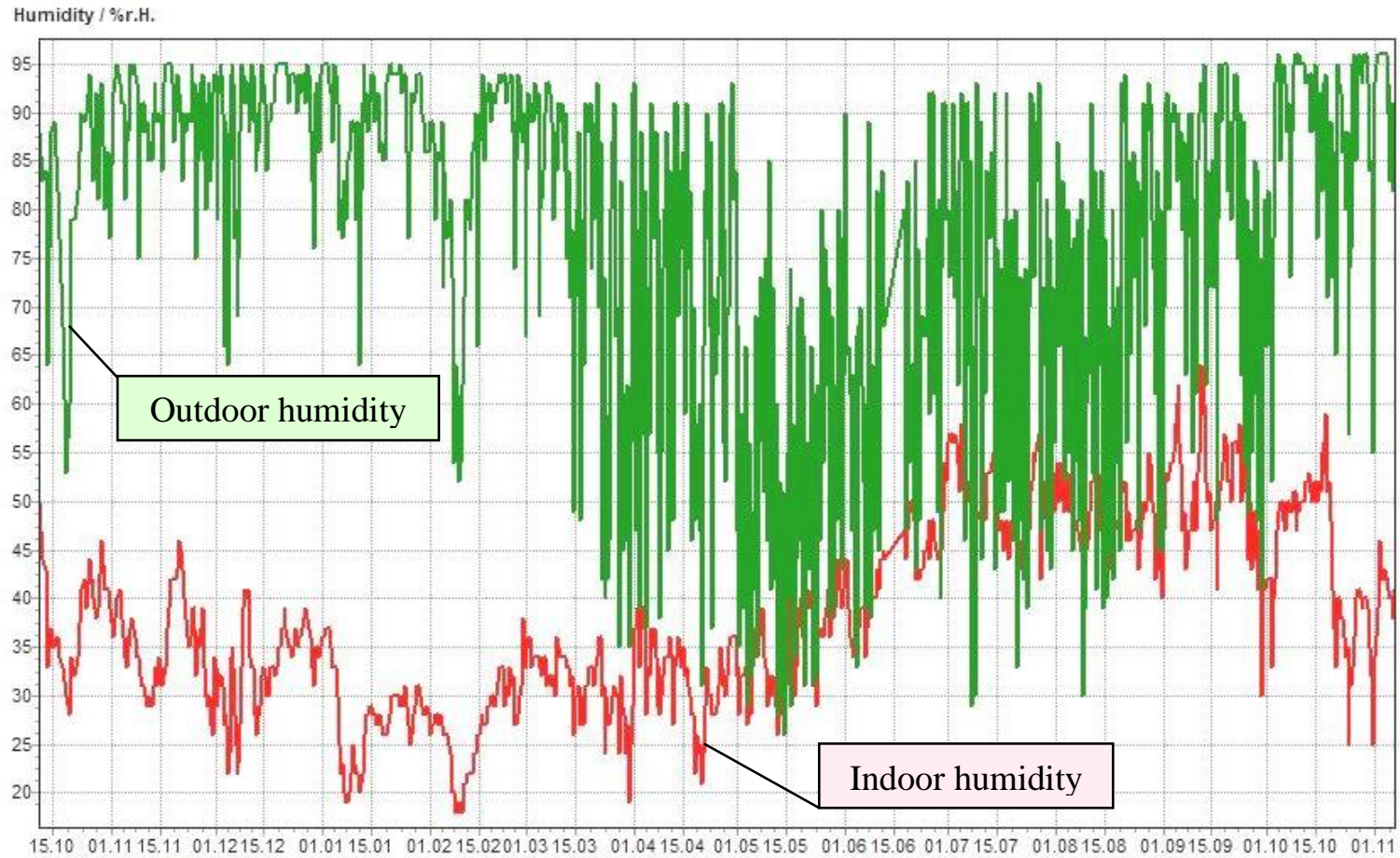

Fig. 3. Variations of the humidity in the experimental room of the building and outdoors

Acceptable relative humidity $(\mathrm{RH})$ varies from country to country. Normal air humidity limits are usually considered to be 40-60\% RH, 50\% RH. In Lithuania during the heating season, according to the above-mentioned Order HN 42: 2009, acceptable RH humidity limits are set from 35 to 60\%. As it can be seen in Fig.3, the acceptable RH limits in the experimental room during the heating season are violated and the minimum $\mathrm{RH}$ is equal to $18 \%$. About $90 \%$ of the days do not fall within the normal $\mathrm{RH}$ zone during the heating season. The indoor RH is then similar to in the Sahara Desert (25\%).

According to the results of the research, a lot of thermal energy in the experimental apartment building can be saved by production and using DHW. The average energy consumptions for heating and keeping hot $1 \mathrm{~m}^{3}$ water during the years 2016-2018 and the average energy consumption over the three years are presented in a bar graph in Fig. 4. Production of $1 \mathrm{~m}^{3}$ hot water $\left(55^{\circ} \mathrm{C}\right)$ during three years required an average of $45.85 \mathrm{kWh}$ of thermal energy, while the continuous maintenance of $1 \mathrm{~m}^{3}$ water temperature $\left(55^{\circ} \mathrm{C}\right.$ in $24 / 7 \mathrm{~h}$ ) required an additional $79.46 \mathrm{kWh}$ of energy. This is why the price of DHW for $1 \mathrm{~m}^{3}$ in our building is about 8.20 EUR instead of 3 EUR. Hot water has a very low demand at night and on days when the majority of dwellers are working or studying. This problem may be solved, and a lot of thermal energy saved by resetting the programmable hot water production controller so that the water temperature is around $40{ }^{\circ} \mathrm{C}$ at night and during the working hours. Average losses make up now 63\%. Significant heat losses in the DHW circulation system are also mentioned in the paper [10].

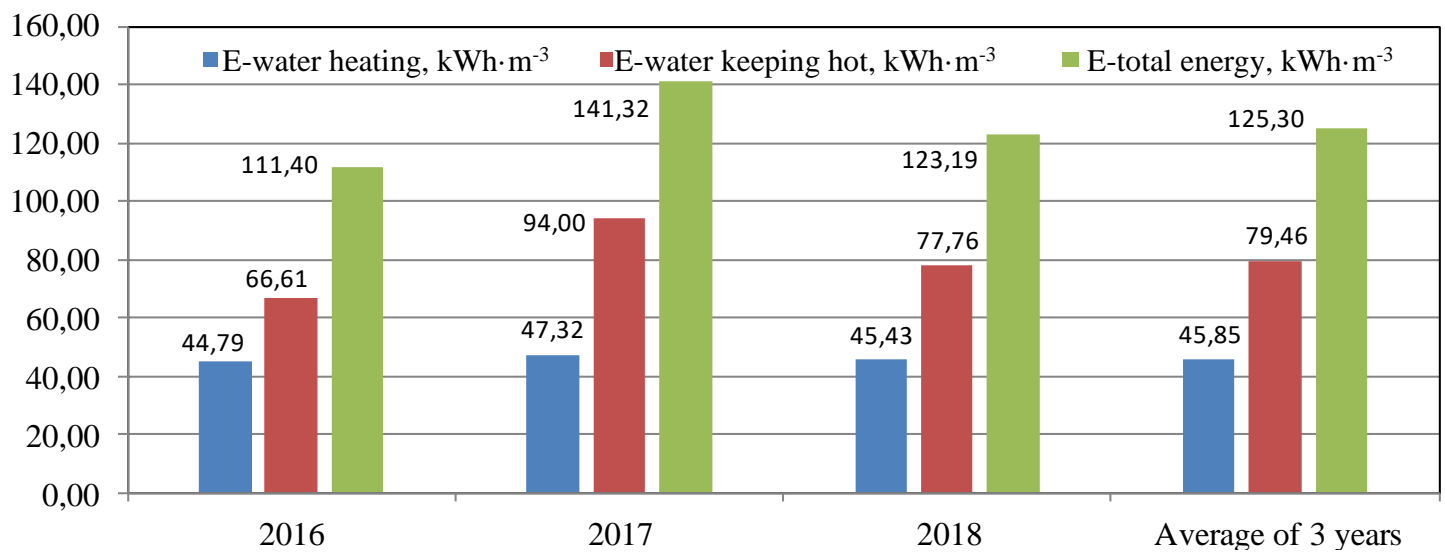

Fig. 4. Average energy consumptions for water heating and keeping it hot 
More opportunities to increase the energy efficiency of a building can arise by inspecting any apartment with a thermovisor or with a thermal camera added smartphone. Usually, the apartment is cooled by windows, doors, external walls, sometimes ceilings (on the top floor) or by the floor, which is above the basement (on the ground floor). Some photographic and thermo graphic pictures of heatwasting parts in building are shown in Fig, 5 and Fig 6. Thermo graphic pictures show very large differences in temperature at the window and at the door. Such windows and doors are cooling the room and must be repaired or replaced in order to avoid wasting of thermal energy.
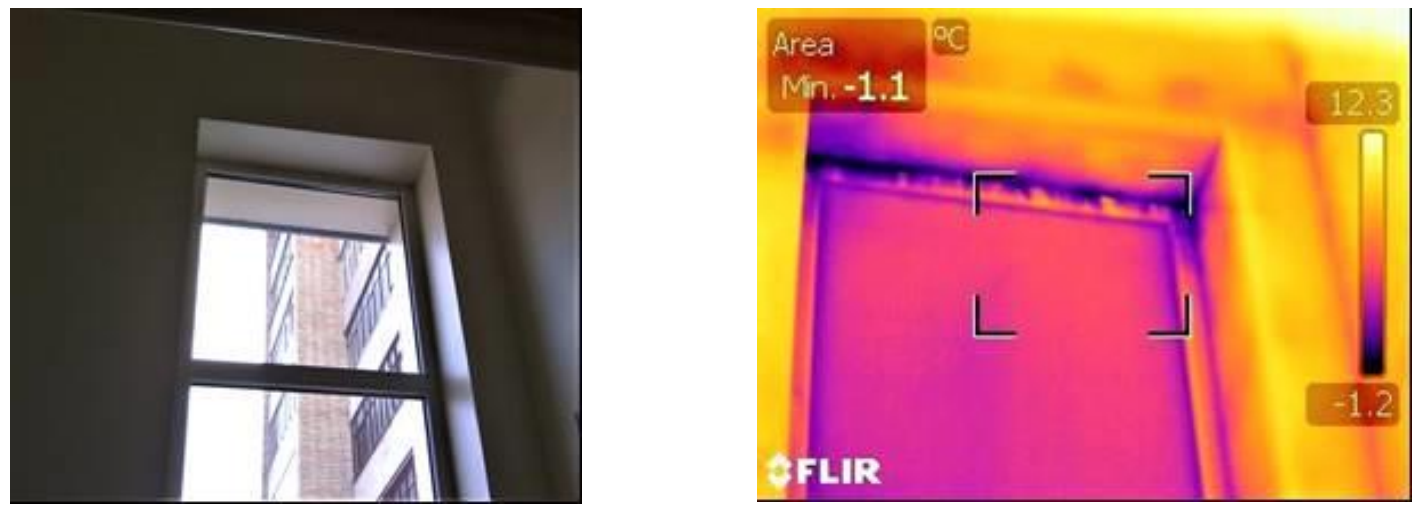

Fig. 5. Photographic and thermo graphic pictures of heat wasting parts in building: windows
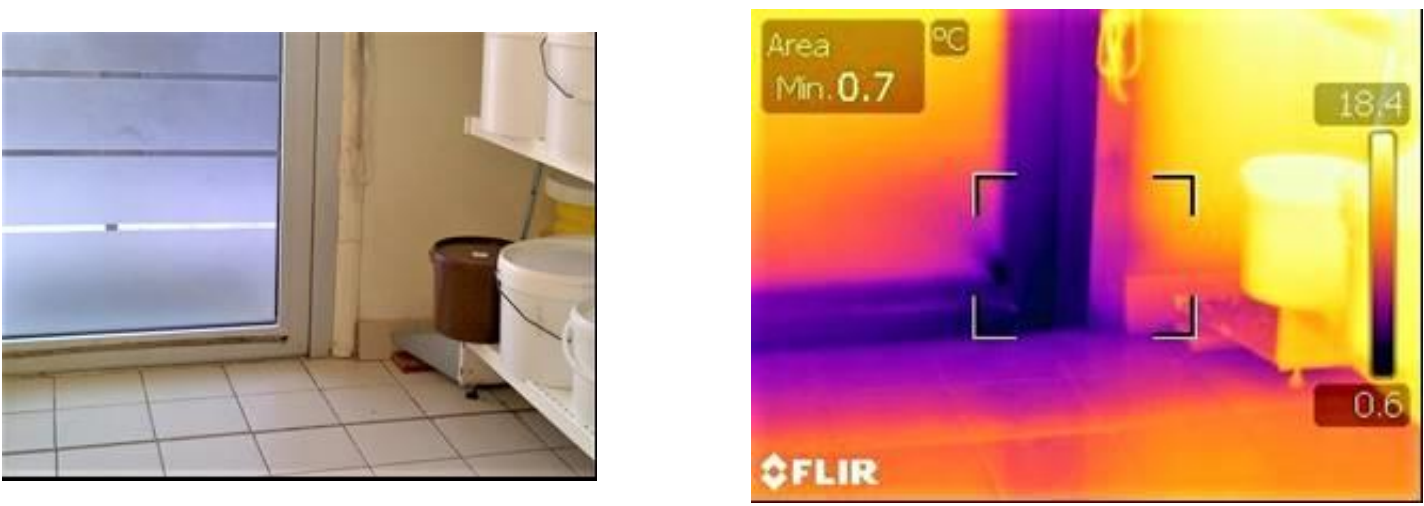

Fig. 6. Photographic and thermo graphic pictures of heat wasting parts in building: doors

The thermo graphic pictures will show to the apartment owner whether it is worth laying thick carpets on the floor above the basement ceiling, linoleum coverings with good thermal insulation, glue thick (3-10 mm) heat-saving wallpaper on external walls and the upper floor ceiling and to use roller blinds with high thermal insulation properties for windows. High thermal insulation roller blinds allow control of solar energy flows into the premises on sunny days There is no doubt that such measures will save quite a significant part of the thermal energy generated by radiators and heat-generating domestic appliances (fridge, TV, PC, gas range or electric stove, dryers, etc.) in any apartment. A modern indoor ventilation system with recuperators would also help save heat energy and maintain fresh air with normal $\mathrm{CO}_{2}$ concentration (1000 ppm) on the premises.

On the other hand, apartment owners can save heat energy with thermostats by setting lower room temperatures. According to the German Museum in Munich, lowering the air temperature by $1{ }^{\circ} \mathrm{C}$ reduces the heating fee by $6 \%$. In addition, a large proportion of doctors are of the opinion that cooler air and hardening with cold water are more beneficial to health. Thus, the optimal air temperature in apartments could be $18-20^{\circ} \mathrm{C}$. DHW has another significant potential for heat energy saving.

The energy efficiency of buildings continues to increase. Modern high-class residential houses presently are required to have limited energy needs (efficient insulation of the building, high-class efficient household appliances), efficient operation of thermal installations, energy efficiency of lighting installations (recommended efficiently controlled LED bulbs), at least partial use of solar energy for the production of DHW and electricity for the needs of a building. One of the main goals of researches in this area is to meet all the energy needs of residential buildings exclusively from renewable energy sources $[11 ; 12]$. The most favourable region for this is the seaside. 


\section{Conclusions}

1. The measured data of average heat consumption for heating of a building and heat loss in the pipeline will be used in the next project to evaluate energy-saving measures in flats.

2. Microclimate studies in a heated room revealed deviations from the optimal air temperature and relative humidity parameters due to the room overheating. Reducing the air temperature could improve the humidity and save a part of thermal energy.

3. A study of the hot water system revealed a very high waste of thermal energy through the pipeline, because high water temperature $\left(55^{\circ} \mathrm{C}\right)$ is set permanently $(24 / 7)$. Heat losses could be easily reduced by resetting the programmable hot water production controller.

4. More opportunities to increase the energy efficiency of buildings can be given by inspecting of potentially cooling surfaces in apartments (windows, doors, external walls, etc.) with a thermovisor. Thermal insulation or fixing of cooling parts has to be applied for energy savings.

5. The energy-saving study will be continued in the apartments in accordance with the program prepared under this article. The results of the study will be evaluated in terms of energy savings.

\section{References}

[1] Document of the UK Government. "Sick building syndrome: Guidance for specialist inspectors" (Occupational Hygiene) OC 311/2 [online] [15.03.2021]. Available at: https://www.hse.gov.uk/foi/internalops/ocs/300-399/oc311_2.htm

[2] Position Document on Limiting Indoor Mould and Dampness in Buildings. Approved by ASHRAE Board of Directors. June 27, 2012. Reaffirmed by ASHRAE Technology Council. Atlanta, Georgia, USA: June 27, 2018. $18 \mathrm{p}$.

[3] Technical and policy recommendations to reduce health risks due to dampness and mould. Project Report. Copenhagen: WHO Regional Office for Europe, 2010. 129 p.

[4] Rudd A. US Department of Energy. Expert Meeting: Recommended Approaches to Humidity Control in High Performance Homes. Springfield, VA, USA: Building Science Corporation (BSC), July 2013. 44 p.

[5] Article in the news portal SA.lt. "Tyrimais nustatyta ideali temperatūra biure" (The ideal temperature for office determined by research). June 25, 2019. (In Lithuanian). [online] [15.03.2021]. Available at: https://sa.lt/tyrimais-nustatyta-ideali-temperatura-biure/ .

[6] Baughman A. V. and Arens E. A. Indoor Humidity and Human Health: Part I - Literature review of health effects of humidity-influenced indoor pollutants. ASHRAE Transactions, vol. 102, part 1, pp. 193-211.

[7] Arens E. A. and Baughman A. V. Indoor Humidity and Human Health: Part II - Buildings and Their Systems. ASHRAE Transactions, vol. 102, part 1, 1996, pp. 212-221.

[8] Wolkoff P. Indoor air humidity, air quality, and health - An overview. International Journal of Hygiene and Environmental Health, 221, 2018, pp. 376-390. DOI: 10.1016/j.ijheh.2018.01.015

[9] Hamehkasi M. Effects of low humidity on comfort, health and indoor environmental quality: Literature review. Kansas: Kansas State University, Report, 2016. 55 p.

[10] Selegovskis R., Berzins J., Visockis E. Hot domestic water consumption profile of multiapartment building and its dependency on external conditions. Proceedings of International conference "Engineering for Rural Development". Jelgava, Latvia, May 20-22, 2020, pp. 1102-1107.

[11] Adomavičius V., Valickas J., Petrauskas G. ect. Potential of village house for sustainable energy production. Proceedings of 6th International Conference "Trends in Agriculture Engineering", September 7-9, 2016, Prague, Czech Republic, pp. 17-25. [online] [15.03.2021]. Available at: https://www.researchgate.net/publication/308305426_POTENTIAL_OF_VILLAGE_HOUSE_F OR_SUSTAINABLE_ENERGY_PRODUCTION

[12] Adomavičius V., Valickas J., Petrauskas G. etc. Concept of RES-based microgrid for apartment building. Proceedings of 11th International Conference "Intelligent Technologies in Logistics and Mechatronics Systems", 28-29 April, 2016, Panevėžys, Lithuania, pp. 1-6. [online] [21.03.2021] Available at: https://www.researchgate.net/publication/309430727_Concept _of_RES-based_microgrid_for_apartment_building . 